\title{
Appendix Neuroendocrine Tumor pN1 TNM Finding v8
}

National Cancer Institute

\section{Source}

National Cancer Institute. Appendix Neuroendocrine Tumor pN1 TNM Finding v8. NCI Thesaurus. Code C135154.

Appendix neuroendocrine tumor with regional lymph node metastasis. (from AJCC 8th Ed.) 